\title{
A Chronicle of Organochlorine Contamination in Clear Creek, Galveston and Harris Counties, Texas, 1960-2002, as Recorded in Sediment Cores
}

Clear Creek flows through the Texas Coastal Plain from its headwaters southeast of Houston, Tex., to Clear Lake, which empties into Galveston Bay. Segments of Clear Creek were on the State of Texas 303(d) list ${ }^{1}$ for 1998, 1999, and 2000 as a result of a fish consumption advisory issued by the Texas Department of Health. One of the contaminants for which the fish consumption advisory was issued is the organochlorine pesticide chlordane. Chlordane is a hydrophobic ("waterfearing") contaminant; that is, it adsorbs to sediment at concentrations much greater than those found in water. The study described here sought to answer three questions:

\section{- Does chlordane occur in Clear Creek sediments at present?}

- Is there current loading of chlordane to Clear Creek?

- How has occurrence of chlordane in Clear Creek changed over time?

To answer these questions, the U.S. Geological Survey (USGS), in cooperation with the U.S. Environmental Protection Agency (USEPA), collected and analyzed sediment cores from Clear Creek (fig. 1). Sediment cores sometimes can be used to reconstruct historical trends in concentrations of hydrophobic contaminants (Eisenreich and others, 1989; Van Metre and others, 1997). Cores were collected from five ponds connected to Clear Creek but out of the main channel (fig. 1). Cesium-137 $\left({ }^{137} \mathrm{Cs}\right.$ ) was analyzed in the cores to determine if the sediments in the cores were undisturbed and if the cores reached sediment predating 1964. The two cores that appeared most undisturbed on the basis of ${ }^{137}$ Cs profiles (see sidebar, p. 2) were further subsampled and additional samples analyzed for ${ }^{137}$ Cs, organic carbon, selected organochlorine pesticides (including chlordane), and total polychlorinated biphenyls (PCB).

\section{Key Findings}

- No historical trends in chlordane are recorded in sediment cores from Clear Creek.

- Chlordane was detected in recently deposited sediment, but concentrations were near or below laboratory reporting levels.

- Sediment cores record historical trends in DDE and PCBs; concentrations peaked in the mid-1960s and have declined to concentrations near or below reporting levels.

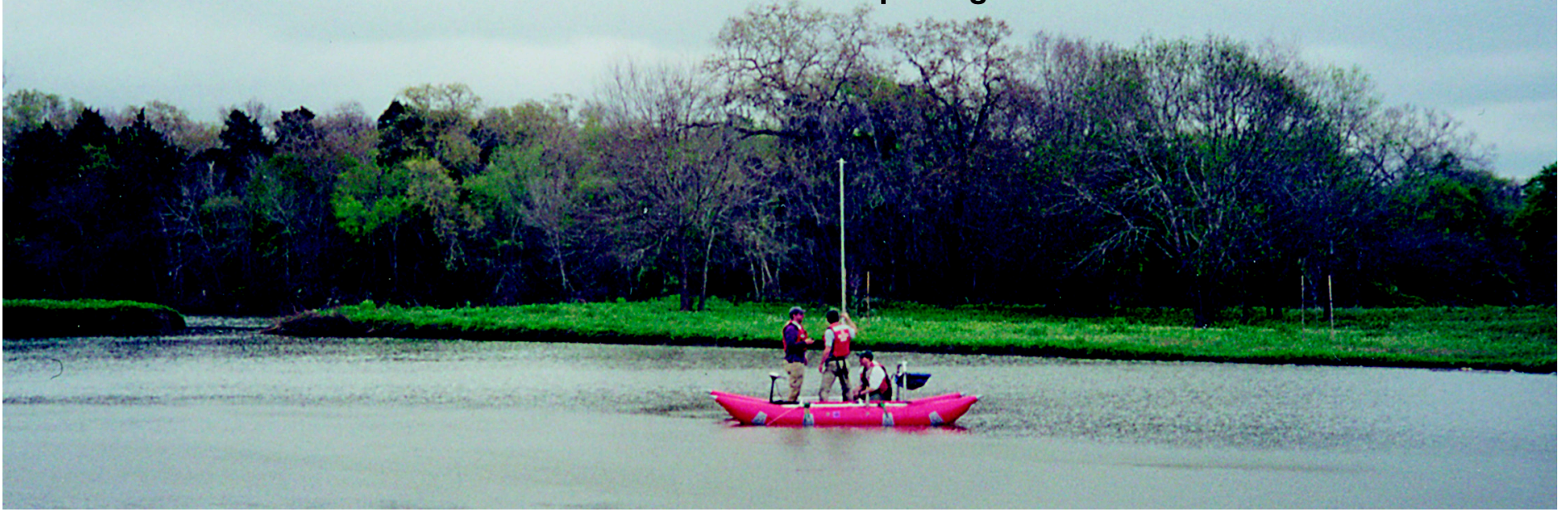

${ }^{1}$ The State of Texas Clean Water Act 303(d) list comprises surface-water bodies in Texas identified by the Texas Commission on Environmental Quality as impaired (do not meet applicable water-quality standards) or threatened (are not expected to meet applicable standards in the near future). Section 303(d) of the Federal Clean Water Act (together with related regulations) requires each State to assess the quality of its surface waters and to develop water-quality improvement strategies for impaired and threatened waters. 


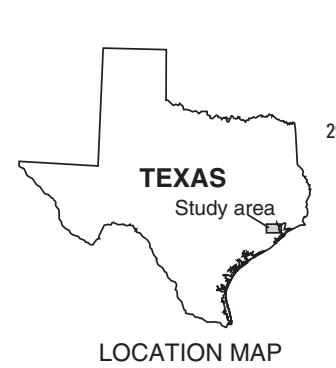

EXPLANATION
- CCA Coring location
and designation

\section{Collection and Age Dating of the Sediment Core}

To find as thick a sequence of undisturbed sediment as possible, the sediment cores were collected from protected ponds connected to Clear Creek, where scouring of sediment was assumed not to occur (fig. 1). The cores were obtained by pushing a plastic cylinder directly into the mud. The two cores chosen for full analysis, CCA and CCD, were 135 centimeters $(\mathrm{cm})$ and $105 \mathrm{~cm}$ long, respectively. The sediment in both cores was olive-green to olive-black clay. In core CCA, a boundary was noted at $133 \mathrm{~cm}$, where the texture changed from that of a clayey lacustrine sediment to that of a crumbly, sticky soil containing root hairs and decaying organic matter. In core CCD lacustrine clays changed to a light, dry, stiff clay at $98 \mathrm{~cm}$. These two depth boundaries were interpreted as indicating the dates of construction of the ponds.

Each core was subsampled by pushing the sediment up through the plastic liner and slicing 5-cm- (CCA) or 4-cm- (CCD) thick layers of sediment off the top (see photo below). Selected samples were analyzed for ${ }^{137} \mathrm{Cs}$ by gamma spectroscopy at a USGS contract laboratory (J. Waddel, Severn Trent Laboratories, Inc., written commun., 2002) and for organochlorine compounds and organic carbon at the USGS

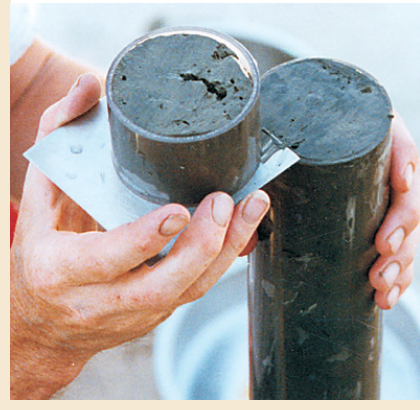

Slicing a subsample from a core for laboratory analysis.

$95^{\circ} 22^{\prime} 30^{\prime \prime} \quad 95^{\circ} 15^{\prime}$ $95^{\circ} 07^{\prime} 30^{\prime \prime}$ $95^{\circ}$
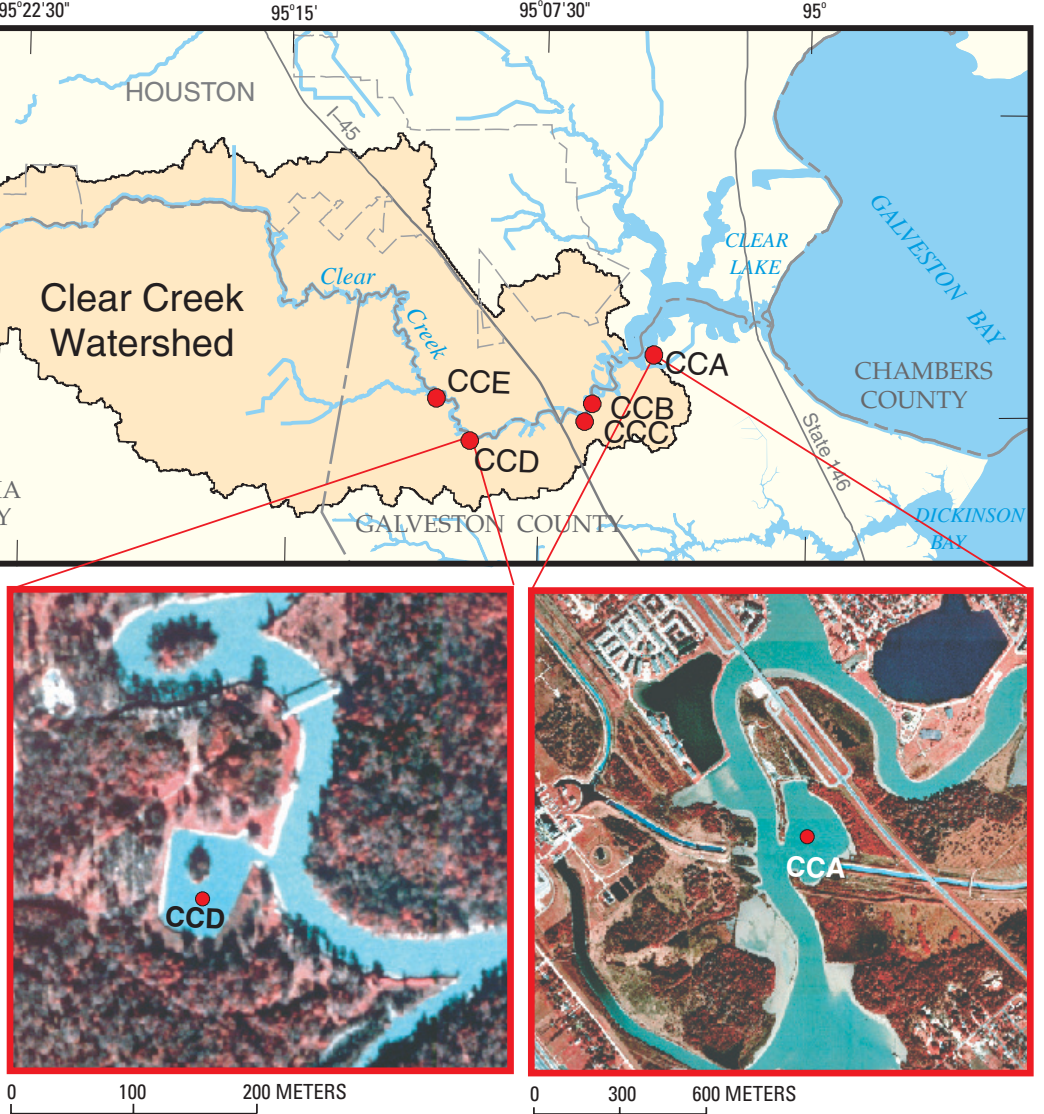

Figure 1. Location of Clear Creek watershed and coring sites and insets of coring sites CCA and CCD, selected for more intensive analysis.

National Water Quality Laboratory in Denver, Colo. Organochlorine compounds were analyzed by dual capillary-column gas chromatography with electron capture detection (Foreman and others, 1995), and organic carbon was measured by combustion (Arbogast, 1996)

The sediment cores were dated on the basis of the ${ }^{137} \mathrm{Cs}$ profile and corroborated with the DDT profile. A by-product of nuclear weapons testing, ${ }^{137} \mathrm{Cs}$ is a radioactive isotope with a half-life of 30.1 years. Concentrations of ${ }^{137} \mathrm{Cs}$ reached their peak in the atmosphere in 1963 and have been decreasing exponentially ever since. Thus an undisturbed sequence of sediment whose lowest parts predate 1963 should contain a ${ }^{137} \mathrm{Cs}$ peak, and ${ }^{137} \mathrm{Cs}$ should decrease exponentially toward the top of the core. Cores CCA and CCD fit this pattern (fig. 2), with the ${ }^{137} \mathrm{Cs}$ concentrations peaking at $117 \mathrm{~cm}$ and $86 \mathrm{~cm}$, respectively. The tidal influence on the downstream part of Clear Creek did not appear to have affected preservation of historical trends in ${ }^{137} \mathrm{Cs}$. The depths in the cores corresponding to the ${ }^{137} \mathrm{Cs}$ peak were assigned an age of 1964 , and a constant mass accumulation rate was assumed from 1964 to the present. Using the computed constant mass accumulation rate for the entire core places the construction of the ponds at 1959 (CCA) and 1957 (CCD), consistent with historical topographic maps of the area, which indicate that the ponds were built after 1955 but before 1969 .

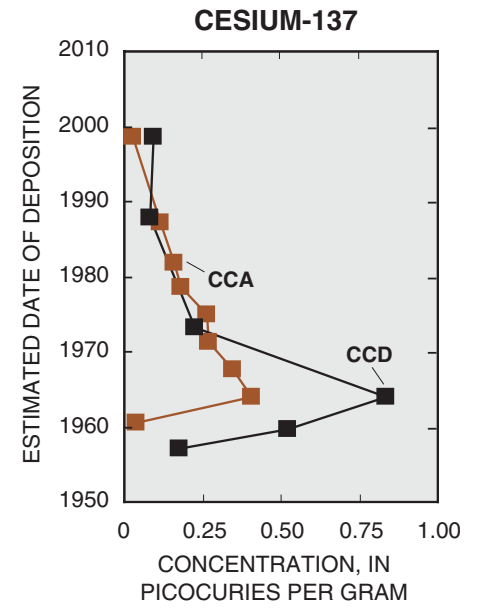

Figure 2. Cesium-137 profiles in sediment cores CCA and CCD indicate undisturbed sediment dating back to pre-1964. 


\section{Trends in Chlordane and Other Organochlorine Compounds}

Of the 14 organochlorine compounds for which the sediment core was analyzed, only chlordane, DDE and DDD (breakdown products of DDT), dieldrin, and PCBs were detected (table 1).

Chlordane, a persistent, bioaccumulative pesticide, was the only organochlorine compound on the 303(d) list. Chlordane was detected in only the top $25 \mathrm{~cm}$ from core CCA and the top $4 \mathrm{~cm}$ from core CCD (fig. 3). All chlordane concentrations detected (table 1) were below the probable effect concentration (PEC), the concentration above which adverse effects on benthic biota are expected (MacDonald and others, 2000). The detection of chlordane at the tops of the cores indicates continued chlordane loading to Clear Creek, albeit at low concentrations. Concentrations could be higher in suspended sediment in the creek-based on investigations in other parts of Texas (Mahler and others, 2002; Mahler and Van Metre, 2003), concentrations of organochlorine compounds usually are higher in suspended stream sediment than in bed sediment.

Historical trends in chlordane use were not measurable in the cores from Clear Creek. Chlordane was widely used from 1948 to 1978; in 1978 the USEPA banned its use on agricultural crops and phased out other above-ground uses over the next 5 years. From 1983 to 1988, the only approved use of chlordane was for termite control, and in 1988 all uses were discontinued (U.S. Environmental Protection Agency, 2003). Historical trends in chlordane have been preserved in cores from many lakes across the Nation, including lakes in Texas, although not in all (Van Metre and others, 1997; Ging and others 1999; Van Metre and Mahler, 1999; Mahler and Van Metre, 2003). It could be that historical trends are preserved only when peak concentrations are very high. On the other hand, the slight increase in chlordane concentrations in core CCA (fig. 3) is consistent with the results of analyses of bottom-feeding fish (carp, smallmouth buffalo, and catfish) and blue crabs (Williams, 1993; Texas Department of Health, 2002), in which median concentrations of chlordane in both media increased significantly from 1993 to 2000 (on the basis of a KruskalWallis test, $\mathrm{p}$-value <.1). Thus the slight increase in chlordane at the top of core CCA could indicate that chlordane is degrading with burial, or it could indicate that loading of chlordane to Clear Creek is increasing. The seafood consumption advisory that was placed on Clear Creek in 1993 was lifted in 2002 because of acceptable levels of contaminants evaluated on a cumulative basis, rather than on a decrease in chlordane concentrations (Texas Department of Health, 2002).

DDE and PCB, in contrast to chlordane, show pronounced historical trends (fig. 4). DDE peaks in the part of the cores corresponding to the mid-1960s. DDT use in the United States peaked in the early 1960s (U.S. Environmental Protection Agency, 1983), so the location of the DDE peak in these cores is consistent with historical use and with the ${ }^{137}$ Cs-based age dating. DDE does not appear to pose an environmental threat, as it was not detected at levels of concern in fish (Texas Department of Health, 2002); concentrations in the upper 70 $\mathrm{cm}$ of the cores (table 1) are less than the threshold effect concentration (TEC), the concentration below which no adverse effects on benthic biota are expected (MacDonald and others, 2000); and peak concentrations are less than the PEC. In core CCD, total PCB (expressed as the sum of Aroclors 1242, 1254, and 1260) peaks in sediment deposited in the late 1960s. This is consistent with observed trends in water bodies across the Nation, in which PCB peaked in the mid-1960s to late 1960s, then decreased following restrictions on PCB use imposed in 1971 (Van Metre and others, 1997, 1998). In

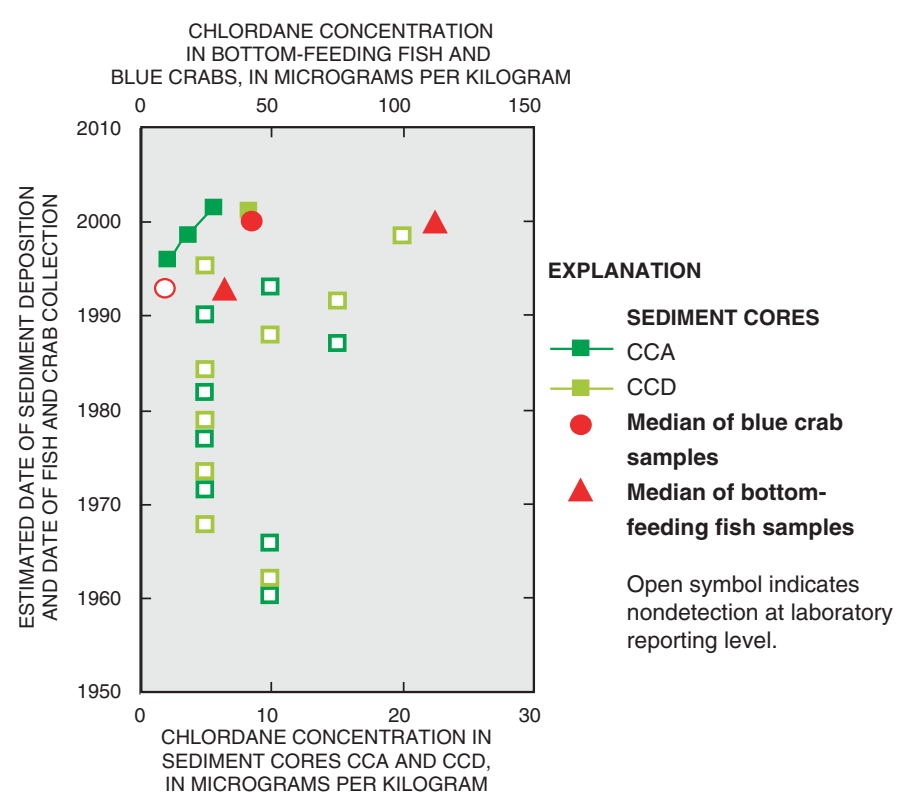

Figure 3. Concentrations of chlordane in sediment cores CCA and CCD (green symbols) and in blue crabs and bottom-feeding fish (red symbols). Data on blue crabs and fish collected in 1993 (Williams, 1993) and 2000 (Texas Department of Health, 2002). Results shown are 1993 median of six blue crab and 15 bottom-feeding fish (carp, smallmouth buffalo, and catfish) and 2000 median of four blue crab and 12 bottom-feeding fish. Low chlordane concentrations in upper part of cores indicate current loading of this pesticide in Clear Creek, whereas nondetections in lower part of cores indicate no historical trend.

Table 1. Concentrations of selected organochlorine compounds in two Clear Creek sediment cores

[See text for additional compounds not detected; $\mathrm{cm}$, centimeters; $\mu \mathrm{g} / \mathrm{kg}$, micrograms per kilogram; E, estimated; <, less than; TEC, threshold effect concentration (MacDonald and others, 2000); --, not applicable; PEC, probable effect concentration (MacDonald and others, 2000)]

\begin{tabular}{|c|c|c|c|c|c|c|c|}
\hline $\begin{array}{c}\text { Core } \\
\text { interval } \\
(\mathrm{cm})\end{array}$ & $\begin{array}{c}\text { Estimated } \\
\text { date of } \\
\text { deposition }\end{array}$ & $\begin{array}{l}\text { Chlor- } \\
\text { dane } \\
(\mu \mathrm{g} / \mathrm{kg})\end{array}$ & $\begin{array}{c}\text { DDE } \\
(\mu \mathrm{g} / \mathbf{k g})\end{array}$ & $\begin{array}{c}\text { DDD } \\
(\mu \mathrm{g} / \mathrm{kg})\end{array}$ & $\begin{array}{l}\text { Dieldrin } \\
(\mu \mathrm{g} / \mathbf{k g})\end{array}$ & $\begin{array}{c}\text { Total } \\
\text { PCB } \\
(\mu \mathrm{g} / \mathrm{kg})\end{array}$ & $\begin{array}{c}\text { Organic } \\
\text { carbon } \\
\text { (percent) }\end{array}$ \\
\hline \multicolumn{8}{|l|}{ CCA } \\
\hline $0-5$ & 2001 & E5.4 & E. 4 & $<1.0$ & $<1.0$ & E6.6 & 1.5 \\
\hline $10-15$ & 1998 & E3.5 & $<1.5$ & $<1.5$ & $<1.5$ & E3.1 & 1.5 \\
\hline $20-25$ & 1996 & E2.2 & E.3 & $<0.5$ & $<.5$ & E3.5 & 1.3 \\
\hline $30-35$ & 1993 & $<10$ & E. 5 & $<1.0$ & $<1.0$ & E6.5 & 1.2 \\
\hline $40-45$ & 1990 & $<5.0$ & E. 4 & $<.5$ & $<.5$ & E6.0 & 1.3 \\
\hline $50-55$ & 1987 & $<15$ & E1.2 & $<1.5$ & $<1.5$ & E24 & 1.3 \\
\hline $65-70$ & 1982 & $<5.0$ & E. 5 & $<.5$ & $<.5$ & E8.9 & 1.3 \\
\hline $80-85$ & 1977 & $<5.0$ & 1.8 & $<.5$ & $<.5$ & E12 & 1.4 \\
\hline $95-100$ & 1971 & $<5.0$ & 2.9 & $<.5$ & $<.5$ & E19 & 1.4 \\
\hline $110-115$ & 1966 & $<10$ & 7.2 & $<1.0$ & $<1.0$ & E36 & 1.6 \\
\hline $125-130$ & 1960 & $<10$ & 6.2 & $<1.0$ & $<1.0$ & E67 & 2.3 \\
\hline \multicolumn{8}{|l|}{ CCD } \\
\hline $0-4$ & 2001 & E8.3 & $<1.5$ & $<1.5$ & $<1.5$ & $<45$ & 1.3 \\
\hline $8-12$ & 1999 & $<20$ & E1.0 & $<2.0$ & $<2.0$ & E29 & 1.2 \\
\hline $16-20$ & 1995 & $<5.0$ & E.3 & $<.5$ & $<.5$ & E4.9 & 1.1 \\
\hline 24-28 & 1992 & $<15$ & E. 3 & $<1.5$ & $<1.5$ & E11 & 1.0 \\
\hline $32-36$ & 1988 & $<10$ & E. 3 & $<1.0$ & $<1.0$ & E11 & 1.1 \\
\hline $40-44$ & 1984 & $<5.0$ & $<.50$ & $<.5$ & $<.5$ & E9.0 & 1.0 \\
\hline $52-56$ & 1979 & $<5.0$ & $<.50$ & $<.5$ & $<.5$ & $<15$ & 1.2 \\
\hline 64-68 & 1973 & $<5.0$ & 1.6 & 1.0 & $<.5$ & 31 & 1.2 \\
\hline $76-80$ & 1968 & $<5.0$ & 4.8 & $<.5$ & .7 & 114 & 1.2 \\
\hline $88-92$ & 1962 & $<10$ & 2.1 & E.4 & $<1.0$ & $<30$ & 1.0 \\
\hline TEC & -- & 3.24 & 3.16 & 4.88 & 1.9 & 59.8 & -- \\
\hline PEC & -- & 17.6 & 31 & 28.0 & 61.8 & 676 & -- \\
\hline
\end{tabular}

contrast, in core CCA, PCB concentrations increase to the boundary with pre-impoundment material, which could indicate that the pond was built a few years later than hypothesized on the basis of the ${ }^{137} \mathrm{Cs}$ 
and DDE profiles, but does not appreciably alter the interpretation of the data. In both cores, peak PCB concentrations do not exceed the PEC, and concentrations in the top $70 \mathrm{~cm}$ of sediment are less than the TEC.

DDD and Dieldrin were not detected in any samples from core CCA; DDD was detected in two samples and dieldrin in one sample from core CCD. The occurrences were in the lower part of the cores in the sections where DDE concentrations were highest (table 1). Concentrations of both compounds were below the TECs.
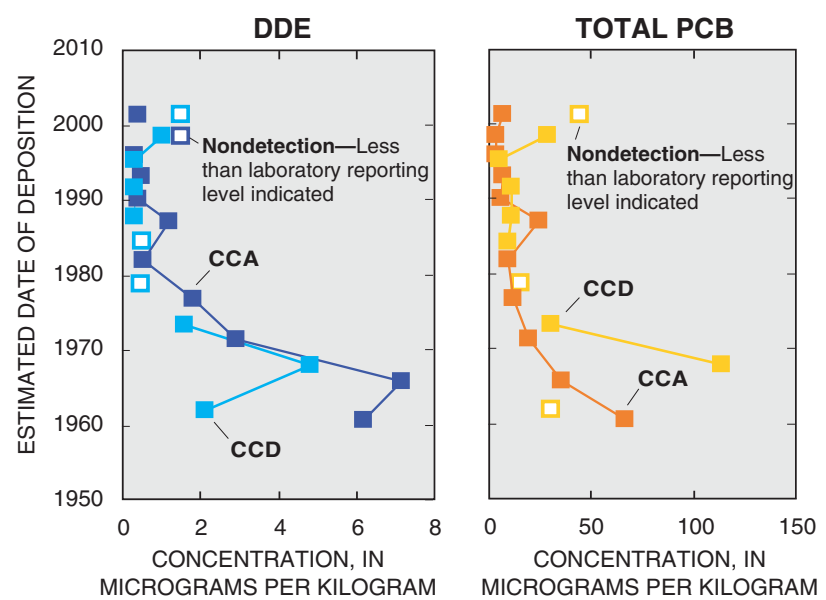

Figure 4. DDE, a breakdown product of DDT, and total PCB show pronounced historical trends, with peaks in sediment cores CCA and CCD coinciding with the period of peak use.

Other organochlorine compounds for which the core sediments were analyzed were not detected. Laboratory reporting levels for aldrin, DDT, endosulfan, endrin, gamma HCH (lindane), heptachlor, heptachlor epoxide, and mirex were 7.0 micrograms per kilogram $(\mu \mathrm{g} / \mathrm{kg}$ ) (one sample) and $2.5 \mu \mathrm{g} / \mathrm{kg}$ or less (all other samples), and methoxychlor was not detected at laboratory reporting levels of 28.0 $\mu \mathrm{g} / \mathrm{kg}$ (one sample) and $10.0 \mu \mathrm{g} / \mathrm{kg}$ or less (all other samples).

\section{What Can We Conclude About Organochlorine Compounds in Clear Creek?}

No historical trends in chlordane were evident in sediment cores collected from two ponds connected to Clear Creek. Chlordane was detected only in the top 25 and $4 \mathrm{~cm}$ of the two cores, respectively, at concentrations not expected to pose a threat to benthic biota. A slight increase in concentration at the top of one of the cores is consistent with an increase from 1993 to 2000 in the median concentration of chlordane detected in blue crabs and bottom-feeding fish. The occurrence of chlordane at the top of the core indicates that there is current loading to Clear Creek at low concentrations. Two other organochlorine compounds, DDE and total $\mathrm{PCB}$, show pronounced historical trends in the cores. Concentrations of DDE and total PCB peaked in sediment deposited in the mid-1960s, coincident with peak use, then decreased following restrictions on their use imposed in the early 1970s. Concentrations of these two organochlorine compounds in recently deposited sediment are at concentrations not expected to pose a threat to benthic biota.

\section{Acknowledgments}

This project was funded by the U.S. Environmental Protection Agency. We thank Sylvia Ritzky and Philip Crocker (USEPA), Roger Miranda (Texas Commission on Environmental Quality), and Jennifer Wilson (USGS) for their helpful comments on the manuscript.

- B.J. Mahler and P.C. Van Metre

\section{References}

Arbogast, B.F., ed., 1996, Analytical methods manual for the Mineral Resource Surveys Program: U.S. Geological Survey Open-File Report 96-525, 248 p.

Eisenreich, S.J., Capel, P.D., Robbins, J.A., and Boubonniere, R.A., 1989, Accumulation and diagenesis of chlorinated hydrocarbons in lacustrine sediments: Environmental Science and Technology, v. 23, no. 9, p. $1,116-1,126$.

Foreman, W.T., Connor, B.G., Furlong, E.T., Vaught, D.G., and Merten, L.M., 1995, Methods of analysis by the U.S. Geological Survey National Water Quality Laboratory-Determination of organochlorine pesticides and polychlorinated biphenyls in bottom sediment by dual capillary-column gas chromatography with electron-capture detection: U.S. Geological Survey Open-File Report 94-140, 78 p.

Ging, P.B., Van Metre, P.C., and Callender, Edward, 1999, Bottom sediments of Lorence Creek Lake, San Antonio, Texas, reflect contaminant trends in an urbanizing watershed: U.S. Geological Survey Fact Sheet 149-99, 4 p.

MacDonald, D.D., Ingersol, C.G., and Berger, T.A., 2000, Development and evaluation of consensus-based sediment quality guidelines for freshwater ecosystems: Archives of Environmental Contamination and Toxicology, v. 39, p. 20-31.

Mahler, B.J., and Van Metre, P.C., 2003, Transport and fate of particleassociated contaminants in small urban watersheds, in 2nd International Symposium on Contaminated Sediments, Quebec City, Canada, May 26-28, 2003, Proceedings: 5 p.

Mahler, B.J., Van Metre, P.C., and Miranda, R.M., 2002, Occurrence of polychlorinated biphenyls (PCBs) on suspended sediment in the Donna Canal, Hidalgo County, Texas, 1999-2001: U.S. Geological Survey Fact Sheet 016-02, 4 p.
Texas Department of Health, 2002, Clear Creek health consultation: Report prepared under cooperative agreement with the Agency for Toxic Substances and Disease Registry, 9 p.

U.S. Environmental Protection Agency, 1983, Analysis of the risks and benefits of seven chemicals used for subterranean termite control: Washington, D.C., Office of Pesticide Programs, EPA-540/9-83-005.

2003, Chlordane: Persistent Bioaccumulative and Toxic (PBT) Chemical Program, accessed June 9, 2003, at URL http://www.epa.gov/pbt/chlordane.htm

Van Metre, P.C., Callender, Edward, and Fuller, C.C., 1997, Historical trends in organochlorine compounds in river basins identified using sediment cores from reservoirs: Environmental Science and Technology, v. 31, no. 8, p. 2,339-2,344.

Van Metre, P.C., and Mahler, B.J., 1999, Town Lake bottom sedimentsA chronicle of water-quality changes in Austin, Texas, 1960-98: U.S. Geological Survey Fact Sheet 183-99, 6 p.

Van Metre, P.C., Wilson, J.T., Callender, Edward, and Fuller, C.C., 1998, Similar rates of decrease of persistent, hydrophobic and particlereactive contaminants in riverine systems: Environmental Science and Technology, v. 32, no. 21, p. 3,312-3,317.

Williams, L.R., [1993], Analysis of risk from consumption of Clear Creek fish: Texas Department of Health report, $34 \mathrm{p}$.

Any use of trade, product, or firm names is for descriptive purposes only and does not imply endorsement by the U.S. Government.

Information on technical reports and hydrologic data related to this study can be obtained from:

District Chief

U.S. Geological Survey

8027 Exchange Dr.

Austin, TX 78754-4733

E-mail: dc_tx@usgs.gov
Phone: (512) 927-3500

FAX: (512) 927-3590

World Wide Web:

http://tx.usgs.gov/ 